\title{
New Locality Record for the Common Cliff Racer, Platyceps rhodorachis rhodorachis (Jan 1863) (Reptilia: Squamata: Colubridae), from Garhwal Himalaya, Northwestern India
}

\author{
Abhishek Singh ${ }^{1}$, Kanchan Puri², and Ritesh Joshi ${ }^{2}$
}

\begin{abstract}
${ }^{1}$ Endangered Flora and Fauna on Earth Conservation Team, Vasant Vihar, Dehradun, 248 006, Uttarakhand, India (effect.abhishek@gmail.com)
\end{abstract} ${ }^{2}$ Conservation \& Survey Division, Ministry of Environment, Forest \& Climate Change, New Delhi, 110 003, India (ritesh_joshi2325@yahoo.com)

$\mathrm{T}$ he Common Cliff Racer (Platyceps rhodorachis rhodorachis) has been recorded from the Kurdish Region and the eastern Caspian Coast to Kyrgyzstan and from the Shatt al-Arab area to at least the border area between Uttarakhand in India and westernmost Nepal; in India, this species has so far been reported from the states of Jammu and Kashmir, Himachal Pradesh (Kasauli, Kullu, vic. Subathu), and Uttarakhand (e.g., vic Almora, Mussoorie, and Pithoragarh Districts) (Schatti et al. 2014). Although only a few records and voucher specimens are available for the Indian Region, several historical records reveal that the species occurs in Jammu and Kashmir State (Murthy and Sharma 1976; Murthy et al. 1979). Whitaker and Captain (2004), however, pointed out that those records were based on the presence of Platyceps $r$. ladacensis in the state. Further, Schatti et al. (2014), based on their long-term systematic study and review of the genus Platyceps, revealed that the nominate subspecies lives above 1,000 $\mathrm{m}$ in Himachal Pradesh and Uttarakhand and at ca. 1,830 $\mathrm{m}$ or higher in the Pithoragarh District in the border region with Nepal.

Smith (1943) described the Indian range of the species as Baluchistan, Chitral, and Gilgit, all of which are now part of Pakistan. Husain and Ray (1995) noted the presence of species in the Pauri and Nainital Districts of Uttarakhand

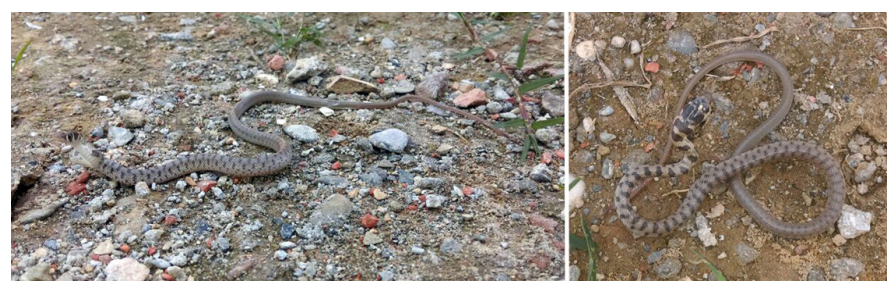

Fig. 1. A juvenile Common Cliff Racer (Platyceps rhodorachis rhodorachis) in natural habitat in the Purola Forest Range in the Tons Valley, Garhwal Himalaya, Uttarakhand, India. Photographs by Abhishek Singh.

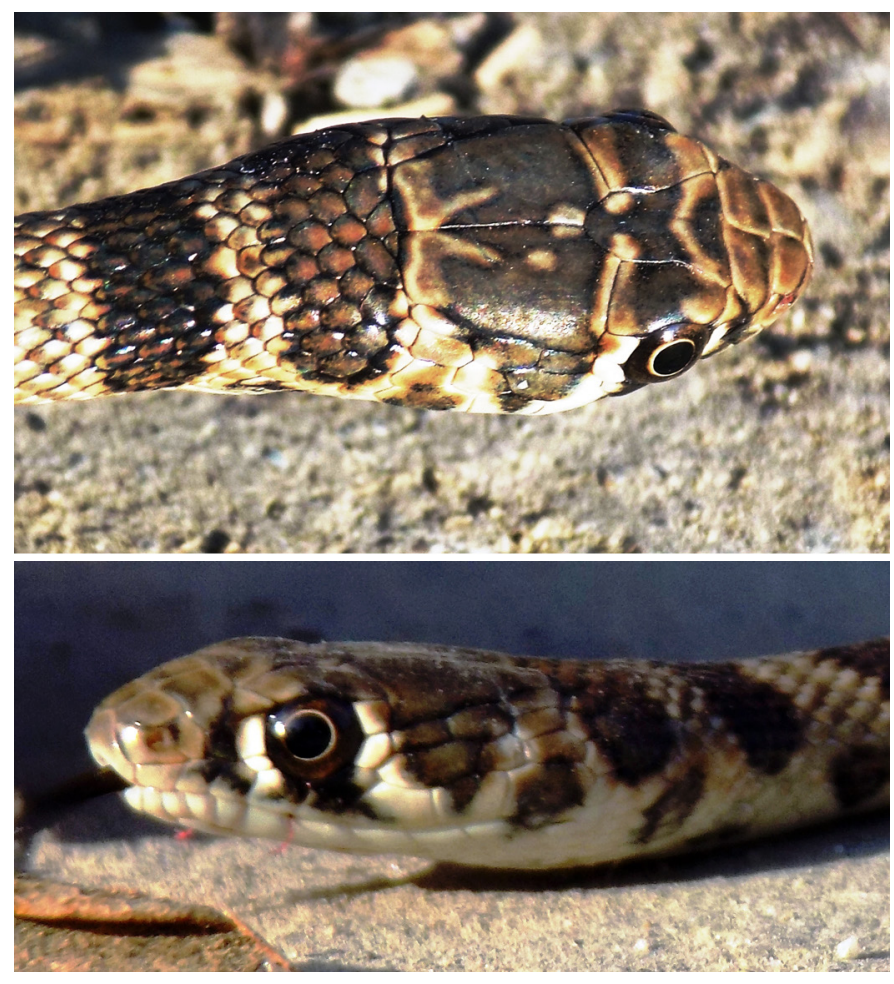

Fig. 2. A Common Cliff Racer (Platyceps rhodorachis rhodorachis) from the Shastra Dhara Road in the Mussoorie Hills, Uttarakhand, India. Photographs by Abhishek Singh.

State, and Sharma (2007) stated that the species occurred in Ladakh in Jammu and Kashmir State. In Uttarakhand, Bahuguna (2008) indicated that the Common Cliff Racer (as Argyrogena rhodorachis) had been recorded from the Corbett Tiger Reserve in addition to some high-elevation areas. These checklists provided neither descriptions nor locality records. Most recently, Ramesh et al. (2015) recorded this species in the Luhri Area of Himachal Pradesh. The paucity of distributional data from northwestern India is evocative of the 
situation outlined for Cliff Racers throughout mountainous northern Pakistan and India (Schatti et al. 2014).

At $1450 \mathrm{~h}$ on 21 October 2016, we encountered a juvenile Common Cliff Racer (sex unknown; Fig. 1) in the Purola Forest Range in the Tons Valley, which lies in the Tons Forest Division under the Yamuna Forest Circle $\left(30^{\circ} 5238.9 \mathrm{~N}, 78^{\circ} 0441.0 \mathrm{E} ; 1,450 \mathrm{~m}\right)$. This snake was in a residential campus of the forest department, about $1 \mathrm{~km}$ from the town of Purola. At 1245 h on 30 November 2016, we observed an individual of unknown sex (Fig. 2) crossing the Dehradun-Shastra Dhara Road in the Mussoorie Hills $\left(30^{\circ} 2255.1 \mathrm{~N}, 78^{\circ} 0658.9 \mathrm{E}\right.$; elev. $\left.810.6 \mathrm{~m}\right)$. Both snakes were photographed and identified based on descriptions in Smith (1943), Schatti and Schmitz (2006), and Schatti et al. (2014). These records confirm the occurrence of the species in the high elevations of the Garhwal Himalaya (Fig. 3) and extend the known distribution of Platyceps $r$. rhodorachis from the states of Jammu and Kashmir and Himachal Pradesh (Khan and Khan 2000; Schatti et al. 2014; Ramesh et al. 2015) to the Tons Valley in Uttarakhand.

Both sightings occurred during the onset of winter. Some of the plant species in the Purola Forest Range were Walnut (Juglans regia), Chir Pine (Pinus roxburghii), China Berry (Melia azedarach), Deodar Cedar (Cedrus deodara), Spiny Pigweed (Amaranthus spinosus), and Congress Grass

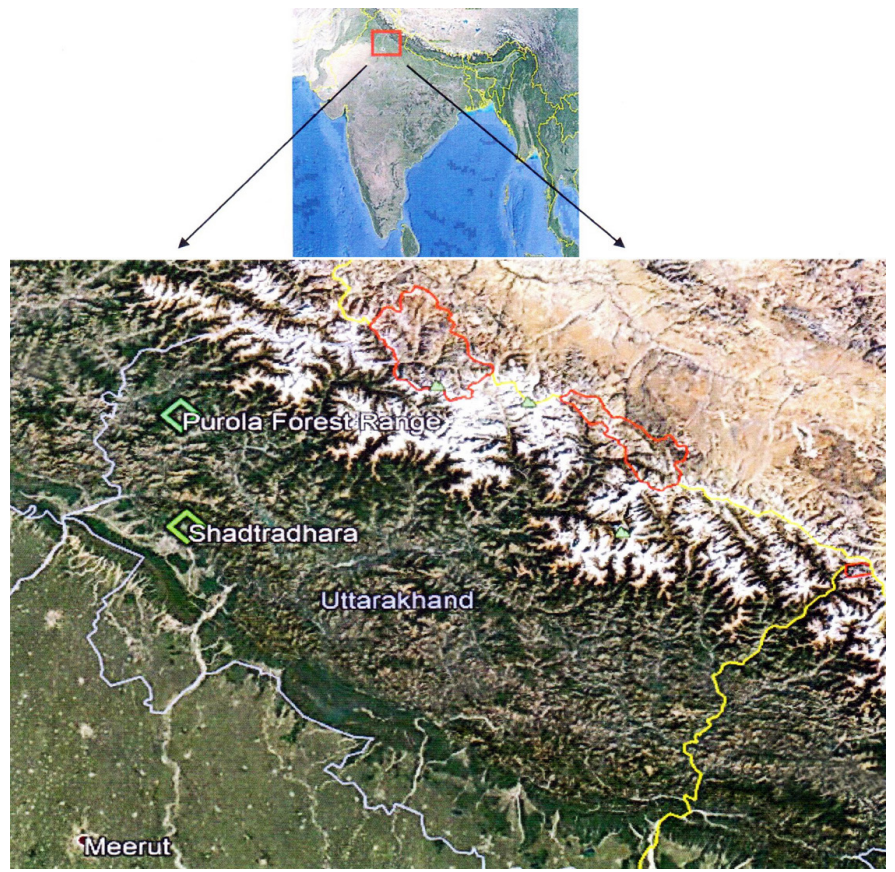

Fig. 3. Google Earth ${ }^{\odot}$ map showing the areas where the Common Cliff Racer (Platyceps rhodorachis rhodorachis) was recorded.
(Parthenium hysterophorus); species in the Dehradun-Shastra Dhara area included Charchara (Flemingia chappar), Curry Tree (Murraya koenigii), Lantana (Lantana camara), Karonda (Carissa carandas), Indian Squirrel Tail (Colebrookea oppositifolia), Jimson Weed (Datura stramonium), and Congress Grass (Parthenium hysterophorus).

The Common Cliff Racer has not yet been assessed for the IUCN Red List. Increasing development and anthropogenic activities affecting streams, shrinkage of natural water sources inside protected areas, expansion of the road network across a long chain of protected habitats, and a lack of awareness among the local people pose potential threats to this species. Because we know so little about its geographic distribution in the high elevations of northwestern India, we recommended that a base-line study be initiated to evaluate the habitats and status of the species.

\section{Acknowledgements}

We thank Frank Tillack, Christoph Kucharzewski, Romulus Whitaker, and Ashok Captain for valuable input and help in confirming the identity of the species. We also thank Sudhakar Sharma and Raj Shekhar Singh for assistance in the field.

\section{Literature Cited}

Bahuguna, A. 2008. Reptilia, pp. 143-157. In: Director, Zoological Survey of India (ed.), Fauna of Corbett Tiger Reserve (Uttarakhand). Conservation Area Series 35, Zoological Survey of India, Kolkata, India.

Husain, A. and P. Ray. 1995. Reptilia, pp. 159-167. In: Director, Zoological Survey of India (ed.), Fauna of Western Himalaya. Part I, Uttar Pradesh. Himalayan Ecosystem Series, Zoological Survey of India, Kolkata, India.

Khan, M.S. and A.Q. Khan. 2000. Three new subspecies of snakes of genus Coluber from Pakistan. Pakistan Journal of Zoology 32: 49-52.

Murthy, T.S.N. and B.D. Sharma. 1976. A contribution to the herpetology of Jammu and Kashmir. British Journal of Herpetology 5: 533-538.

Murthy, T.S.N., B.D. Sharma, and T. Sharma. 1979. Second report on the herpetofauna of Jammu and Kashmir. The Snake 11: 234-241.

Ramesh, C., B. Shanthakumar, A.P. Ramachandran, R.K. Sony, M. Maruthakutti, A. Das, and S. Bhupathy. 2015. Further confirmation for Platyceps rhodorachis (Jan, 1865), from India, with a note on feeding on Cyrtodactylus fasciolatus (Blyth, 1861). Herpetozoa 28: 109-112.

Sharma, R.C. 2007. The Fauna of India and the Adjacent Countries: Vol. III: Reptilia: Serpentes. Zoological Survey of India, Kolkata, India.

Schatti, B. and A. Schmitz. 2006. Re-assessing Platyceps ventromaculatus (Gray, 1834) (Reptilia: Squamata: Colubrinae). Revue Suisse de Zoologie 113: 747768.

Schatti, B., F. Tillack, and C. Kucharzewski. 2014. Platyceps rhodorachis (Jan, 1863) - a study of the racer genus Platyceps Blyth, 1860 east of the Tigris (Reptilia: Squamata: Colubridae). Vertebrate Zoology 64: 297-405.

Smith, M.A. 1943. The Fauna of British India, Ceylon and Burma Including the Whole of the Indo-Chinese Subregion, Reptilia and Amphibia, Vol. III, Serpents. Taylor and Francis, London, United Kingdom.

Whitaker, R. and A. Captain. 2004. Snakes of India, The Field Guide. Draco Books, Chennai, India. 